\title{
POTENSI ANTIOKSIDAN PADA BUAH LOKAL PAPUA
}

\section{ANTIOXIDANT POTENTIAL OF LOCAL FRUITS FROM PAPUA}

\author{
Inna Martha Rumainum ${ }^{1) *}$, Veronica Tuhumena ${ }^{1)}$ \\ ${ }^{1)}$ Jurusan Budidaya Pertanian, Fakultas Pertanian, Universitas Papua \\ Jl. Gunung Salju Amban, Manokwari 98314 \\ *Email: innarumainum@gmail.com
}

Diserahkan [28 Juni 2018]; Diterima [5 Agustus 2018]; Dipublikasi [31 Agustus 2018]

\section{ABSTRACT}

The aim of this article is to review the phytochemical compounds in three local fruits from Papua, i.e., red fruit, mahkota dewa and matoa, and to analyze their potential as antioxidant source. Fruit is known to contain various beneficial nutrients. Antioxidant compounds that contained in fruit have important function against cardiovascular diseases. Red fruit contains tocopherol and carotenoid compounds that actively act as antioxidant. Polyphenols that found in mahkota dewa and matoa also have important rules in free radicals scavenging. These compounds have been demonstrated to suppress cancer cells in vitro.

Keywords: Antioxidant, Fruit, Polyphenols, Papua island

\section{ABSTRAK}

Tujuan dari artikel ini ialah untuk mengulas kandungan fitokemikal yang terdapat pada buah merah, mahkota dewa dan matoa serta mengkaji potensinya sebagai sumber antioksidan. Buah mengandung berbagai jenis nutrisi yang bermanfaat bagi manusia. Senyawa antioksidan yang terkandung di dalam buah memiliki khasiat mencegah penyakit kardiovaskuler. Buah merah mengandung senyawa tokoferol dan senyawa karotenoid yang tinggi yang berperan aktif sebagai antioksidan. Senyawa polifenol yang terkandung di dalam buah mahkota dewa dan matoa juga berperan penting dalam menangkap radikal bebas di dalam tubuh. Senyawa-senyawa tersebut telah teruji secara in vitro mampu menghambat pertumbuhan sel-sel kanker.

Kata Kunci: Antioksidan, Buah, Polifenol, Papua

\section{PENDAHULUAN}

Buah diketahui mengandung berbagai jenis nutrisi penting yang menguntungkan bagi kesehatan manusia. Buah mengandung karbohidrat, asam organik, asam lemak serta metabolit sekunder seperti vitamin, senyawa fenol, karotenoid, flavonoid dan sebagainya (Haminiuk et al., 2012; Tohge et al., 2014). Identifikasi dan karakterisasi senyawasenyawa aktif tersebut telah banyak dilakukan sehubungan dengan efek biologisnya seperti antioksidan, antimikrobial, antibakterial dan antiviral. Oleh sebab itu, kajian terhadap senyawa fitokemikal pada buah telah mendapat banyak perhatian para peneliti beberapa dekade terakhir. Selain itu, meningkatnya angka kematian akibat penyakit kardiovaskuler memerlukan langkah alternatif dalam pengobatan.

Penyakit kardiovaskuler (cardiovascular diseases disingkat CVDs) merupakan penyebab kematian tertinggi di dunia (WHO, 2017). Berdasarkan data yang dipublikasi oleh WHO (2017) terdapat 17,7 juta orang meninggal akibat CVDs. CVDs disebabkan salah satunya oleh stres oksidatif. Stres oksidatif di dalam sel tubuh manusia disebabkan oleh adanya radikal bebas (free radicals). Radikal bebas merupakan molekul yang memiliki satu atau beberapa elektron tak berpasangan sehingga bersifat reaktif dan tidak stabil. Karena sifatnya yang reaktif maka radikal bebas cenderung bereaksi dengan molekul lain untuk mendapatkan elektron tambahan. Beberapa jenis radikal bebas antara lain super oksida $\left(\mathrm{O}_{2}^{-}\right)$, hidroksil $\left(\mathrm{OH}^{-}\right)$, hidroperoksil $\left(\mathrm{HOO}^{-}\right)$, nitrit oksida $\left(\mathrm{NO}^{-}\right)$ dan sebagainya. Molekul-molekul tersebut dikenal sebagai spesies oksigen reaktif (reactive oxygen species disingkat ROS). Pada dasarnya ROS terdapat di setiap makhluk hidup, dihasilkan dari berbagai proses metabolisme yang terjadi di dalam sel. ROS juga memiliki peranan penting dalam sinyal transduksi. Tetapi ROS dapat menjadi berbahaya ketika menyerang molekul lain untuk menangkap elektron. Ketika suatu molekul atau senyawa 
Tabel 1. Kandungan senyawa antioksidan pada buah lokal Papua

\begin{tabular}{|c|c|c|c|}
\hline $\begin{array}{l}\text { Local } \\
\text { name }\end{array}$ & Scientific name & $\begin{array}{l}\text { Phytochemical } \\
\text { compound }\end{array}$ & Concentration \\
\hline \multirow{7}{*}{$\begin{array}{c}\text { Red fruit } \\
\text { (Buah } \\
\text { merah) }\end{array}$} & \multirow[t]{7}{*}{$\begin{array}{c}\text { Pandanus } \\
\text { conoideus Lam. }\end{array}$} & Fenol & 90-742 ppm (Sarunggallo et al., 2015) \\
\hline & & a-tokoferol & 52-272 ppm (Sarunggallo et al., 2015) \\
\hline & & & 111-261,8 mg/Kg (Sarunggallo et al., 2014) \\
\hline & & & 145 mg/g (Rohman et al., 2012) \\
\hline & & g-tokoferol & 16-287 ppm (Sarunggallo et al., 2015) \\
\hline & & b-karoten & 14-27 mg/Kg (Sarunggallo et al., 2014) \\
\hline & & & $3 \mathrm{mg} / \mathrm{g}$ (Rohman et al., 2012) \\
\hline \multirow[t]{4}{*}{$\begin{array}{c}\text { Mahkota } \\
\text { dewa }\end{array}$} & \multirow[t]{4}{*}{$\begin{array}{c}\text { Phaleria } \\
\text { macrocarpa } \\
\text { (Scheff.) Boerl }\end{array}$} & $\begin{array}{l}\text { Kaempferol-3- } O \text { - } \\
\text { glukosida }\end{array}$ & \\
\hline & & Mangiferin & reviewed by Hendra (2012) \\
\hline & & Asam galat & \\
\hline & & Benzofenon & \\
\hline \multirow[t]{3}{*}{ Matoa } & \multirow[t]{3}{*}{ Pometia pinnata } & Fenol & $\begin{array}{l}\text { 208-715 mg/L (Faustina dan Santoso, } \\
\text { 2014) }\end{array}$ \\
\hline & & Tannin & \\
\hline & & Saponin & \\
\hline
\end{tabular}

kehilangan elektron maka molekul atau senyawa tersebut akan menjadi reaktif dan pada akhirnya menjadi radikal bebas. Proses tersebut akan menuntun pada terjadinya peroksidasi lipid yang akan menyebabkan antara lain disintegrasi membran sel dan oksidasi DNA dan protein (Poprac et al., 2017). Oleh sebab itu, keberadaan senyawa bioaktif yang dapat mencegah oksidasi (disebut antioksidan) seperti senyawa fenolik, karotenoid, tokoferol pada buah menjadi sangat penting.

Pulau Papua telah dikenal memiliki biodiversitas yang tinggi. Terdapat banyak tanaman endemik yang berpotensi sebagai sumber antioksidan. Review ini akan fokus pada tiga jenis buah lokal Papua yaitu buah merah, mahkota dewa dan matoa. Buah merah telah banyak dikenal memiliki kandungan nutrisi seperti karotenoid dan tokoferol yang tinggi (Rohman et al., 2012; Sarunggalo et al., 2015). Mahkota dewa (Soeksmanto et al., 2007) dan matoa (Faustina and Santoso, 2014) mengandung senyawa polifenol. Review ini bertujuan untuk mengkaji kandungan senyawasenyawa fitokemikal yang terdapat pada ketiga buah lokal Papua tersebut serta potensinya sebagai sumber antioksidan.

\section{HASIL DAN PEMBAHASAN}

\section{BUAH MERAH (Pandanus conoideus} Lam.)

\section{Kandungan Senyawa Antioksidan}

Buah merah diklasifikasikan ke dalam famili Pandanaceae. Buah merah tersebar secara luas di pulau Papua. Pada umumnya buah merah digunakan oleh masyarakat lokal sebagai makanan atau obat tradisional. Beberapa dekade terakhir menunjukkan peningkatan minat terhadap buah merah oleh karena senyawa-senyawa fitokemikal yang terkandung. Produk komersial yang telah beredar saat ini ialah minyak buah merah. Minyak buah merah (red fruit oil, RFO) dilaporkan mengandung $\alpha$-karoten, $\beta$-karoten, $\beta$-kriptoksantin, $\alpha$ tokoferol, $\gamma$-tokoferol dan asam lemak antara lain asam olear, asam linoleate dan asam palmitat (Rohman et al., 2012; Sarunggalo et al., 2015). Analisis terhadap 9 klon buah merah dari dataran rendah dan dataran tinggi di Papua menunjukkan bahwa buah merah 
mengandung 49.4-64.5 g oleat, 4.1-16.1 g linoleate, 14.1-19.2 g palmitate, 90-742 ppm fenol, 52-272 ppm $\alpha$-tokoferol dan 16-287 ppm $\gamma$-tokoferol (Tabel 1). Keberadaan dan konsentrasi dari senyawasenyawa aktif tersebut bergantung pada varietas dan kondisi lingkungan (Sarunggalo et al., 2015). Buah merah juga mengandung $\beta$-karoten dengan konsentrasi tinggi yaitu 3 $\mathrm{mg} / \mathrm{g}$ (Rohman et al., 2012) (Tabel 1).

\section{Aktivitas Antioksidan}

Tokoferol dan karotenoid merupakan senyawa antioksidan yang dominan terkandung di dalam buah merah (Agnesa et al., 2017). Sejauh ini analisis mengenai aktivitas antioksidan dari buah merah dilakukan secara in vitro. Penelitian yang dilakuakn terhadap mencit putih menunjukkan bahwa pemberian $0,12 \mathrm{~mL}$ ekstrak buah merah mennurunkan low density lipoprotein (LDL) level (Agnesa et al., 2017). Peningkatan LDL, terutama LDL-kolesterol (LDL-C) menyebabkan hiperkolesterolemia suatu kondisi dimana kandungan kolesterol di dalam darah melebihi batas normal (Napoli et al., 2012). Tokoferol pada buah merah memainkan fungsi penting dalam mencegah oksidasi LDL oleh ROS dengan cara sebagai pendonor elektron.

Ekstrak buah merah juga dilaporkan memiliki efek hepaprotektif. Penelitian yang dilakukan oleh Nugraha et al. (2008) melaporkan bahwa ektrak buah merah mencegah nekrosis sel hati pada mencit jantan yang diberi perlakuan $\mathrm{CCl}_{4}$. Hal tersebut diidentifikasi dengan menurunnya aktivitas enzim SGPT dan SGOT. Hal itu menunjukkan bahwa tokoferol dan karotenoid yang terkandung pada buah merah berhasil menekan aktivita ROS.

\section{MAHKOTA DEWA (Phaleria macrocarpa [Scheff] Boerl) Kandungan Senyawa Antioksidan}

Mahkota dewa diklasifikasikan ke dalam famili Thymelaceae dan tersebar baik di dataran rendah maupun dataran tinggi. Buah mahkota dewa biasanya digunakan dalam pengobatan tradisional. Di lain sisi, mahkota dewa juga digunakan sebagai racun untuk menangkap ikan. Senyawa-senyawa aktif yang terkandung di dalam buah makhota dewa antara lain terpenoid dan turunan senyawa fenol (Tabel 1). Saponin merupakan senyawa antioksidan dengan kandungan tertinggi pada buah mahkota dewa (Fiana dan Oktaria, 2016).

\section{Aktivitas Antioksidan}

Sejauh ini uji aktivitas antioksidan pada mahkota dewa masih terbatas. Buah mahkota dewa sendiri telah diketahui memiliki khasiat farmakologi namun bukti saintifik masih terbatas. Beberapa uji aktivitas antioksidan mahkota dewa yang telah dilakukan antara lain terhadap pertumbuhan sel HeLa (Radji et al., 2010) dan sel leukemia L1210 (Lisdawati, 2005). Selain itu, ekstrak buah mahkota dewa memiliki efek antioangiogenik yaitu menghambat pertumbuhan pembuluh darah pada sel-sel muda, mengimplikasikan peranannya dalam penghamabatan pertumbuhan sel-sel kanker (Mustafida et $a l ., 2014)$. Senyawa fenolik yang terkandung di dalam buah makhkota dewa bereaksi terhadap ROS yang dihasilkan oleh sel kanker dan menurunkan toksisitas ROS (Lauretta et al., 2013). Selain itu, aktivitas antioksidan buah mahkota dewa dipengaruhi oleh kematangan buah. Buah muda memiliki aktivitas antioksidan yang lebih kuat bila dibandingkan dengan buah yang telah matang (Soeksmanto et al., 2007). Senyawasenyawa aktif seperti fenol umumnya terkandung dalam jumlah yang tinggi pada buah muda dan kemudian akan termodifikasi menjadi senyawa-senyawa turunan ketika buah matang (Treutter, 2001). Hal inilah yang menyebabkan buah muda memiliki aktivitas antioksidan yang tinggi.

\section{MATOA (Pometia pinnata)}

\section{Kandungan Senyawa Antioksidan dan} Aktivitas Antioksidan

Matoa yang termasuk dalam famili Sapindaceae tersebar di seluruh pulau Papua. Tanaman matoa memiliki berbagai fungsi antara lain batang matoa dimanfaatkan dalam industri kayu, daun matoa sebagai obat tradisional dan buah serta biji matoa dikonsumsi sebagai makanan. Meskipun buah matoa telah 
dikenal secara luas namun informasi terkait khasiat antioksidannya belum banyak diketahui. Faustina dan Santoso (2014) melaporkan bahwa kulit buah matoa mengandung tannin, fenolik dan saponin. Total senyawa fenolik yang terkandung di dalam kulit buah matoa berkisar antara 208 mg/L hingga $715 \mathrm{mg} / \mathrm{L}$ (Tabel 1). Jumlah ini sebanding dengan jumlah senyawa fenolik yang terkandung di dalam buah merah, mengindikasikan bahwa kulit buah matoa memiliki aktivitas antioksidan yang tinggi. Faustina dan Santoso (2014) juga melaporkan aktivitas antimikrobial ektrak kulit buah matoa terhadap bakteri. Hasil tersebut menunjukkan potensi kulit buah matoa sebagai sumber antioksidan. Tetapi sejauh ini belum ada uji aktivitas antioksidan yang dilakukan terhadap daging buah matoa.

\section{Prospek Buah Lokal Papua Sebagai Sumber Antioksidan}

Buah lokal Papua yaitu buah merah, mahkota dewa dan matoa memiliki kandungan senyawa-senyawa aktif seperti fenol, flavonoid, karotneoid, tokoferol dan sebagainya. Senyawa-senyawa aktif tersebut memiliki fungsi penting sebagai penangkap radikal bebas di dalam tubuh manusia. Buah merah dengan kandungan tokoferol dan karotenoid yang tinggi telah menjadi pusat perhatian para ahli beberapa dekade terakhir sehingga tidak diragukan lagi potensinya sebagai sumber antioksidan.

Di lain pihak, sedikit informasi yang tersedia mengenai identifikasi dan karakterisasi senyawa-senyawa aktif yang terkandung di dalam buah mahkota dewa serta konsentrasi senyawa-senyawa tersebut. Kandungan terbanyak pada buah mahkota dewa ialah saponin yang bekerja sebagai penghambat (inhibitor) enzim $\alpha$-glukosidase sehingga menurunkan kadar glukosa dalam darah (Fiana dan Oktaria, 2016). Beberapa penelitian lainnya juga telah mendemonstrasikan aktivitas antioksidan ekstrak buah mahkota dewa (Faried et al., 2007; Hakim et al., 2004; Tjandrawinata et al., 2010). Dalam penelitian lebih lanjut karakterisasi senyawa aktif buah mahkota dewa secara spektrometri untuk menganalisa lebih dalam kinerja senyawa-senyawa tersebut sebagai antioksidan.

Kulit buah matoa memiliki prospek yang menjanjikan sebagai sumber antioksidan dibandingkan dengan daging buah berdasarkan hasil penelitian yang ada (Faustina and Santoso, 2014). Penelitian lebih lanjut sangat diperlukan untuk mengetahui potensi sebagai sumber antioksidan yang dimiliki oleh buah matoa baik daging buah maupun kulit buah.

\section{KESIMPULAN}

Tiga buah lokal Papua yaitu buah merah, mahkota dewa dan matoa memiliki kandungan senyawa antioksidan yang tinggi. Beberapa senyawa antioksidan tersebut antara lain polifenol, karotenoid dan tokoferol yang memiliki efek antimikrobial, antibakterial dan antiviral. Hal ini menunjukkan bahwa ketiga buah lokal Papua memiliki potensi sebagai sumber antioksidan. Dengan sedikit informasi yang tersedia maka dibutuhkan penelitian lebih detail mengenai kuantitas dan kualitas senyawa aktif yang terkandung pada buah mahkota dewa dan buah matoa.

\section{DAFTAR PUSTAKA}

Agnesa, O. S., J. Waluyo, J. Prihatin, S. R. Lestari. 2017. Potensi buah merah (Pandanus conoideus Lam.) dalam menurunkan kadar LDL darah tikus putih. Bioeksperimen 3(1): 48-57.

Faried, A., D. Kurnia, L. S. Faried, N. Usman, T. Miyazaki, H. Kato. H. Kuwano. 2007. Anticancer effects of gallic acid isolated from Indonesia herbal medicine, Phaleria macrocarpa (Scheff) Boerl., on human cancer cell lines. Int. J. Oncol. 30: 605-613.

Faustina, F. C., F. Santoso. 2014. Extraction of fruit peels of Pometia pinnata and its antioxidant and antimicrobial activities. J. Pascapanen. 11(2): 8088.

Fiana N., D. Oktaria. 2016. Pengaruh kandungan saponin dalam daging buah mahkota dewa (Phaleria macrocarpa) terhadap penurunan 
kadar glukosa darah. Majority 5(4): 128-132.

Hakim, R. W., A. Nawawi, I. K. Adnyana, S. A., Achmad, L. Makmur, E. H. Hakim, Y. M. Sjah, M. Kitajima. 2004. Benzophenone glucoside from the red fruit of mahkota dewa Phaleria macrocarpa and its activity toward DPPH and murine leukemia P-388 cells. Bul. Ind. Soc. Nat. Product Chem. 4: 67-70.

Haminiuk, C. W. I., G. M. Maciel, M. S. V. Plata-Oviedo, R. M. Peralta. 2012. Phenolic compounds in fruits - an overview. Int. J. Food Sci. Tech. 47: 2023-2044.

Hendra, P. 2012. Review: Peluang mahkota dewa sebagai antikanker. J. Farmasi Sains dan Kom. 9(2): 104-107.

Lauretta, M., Muhartono. A. Wahyuni. 2013. The effect of Phaleria macrocarpa (Schef) Boerl. fruit agaisnt 7,12dimethylbenz $[\alpha]$ anthracene

(DMBA)-induced on lung histopathology appearance in rat. Med. J. Lampung Univ. 3(3): 114123.

Lisdawati, V. 2005. Brine shrimp lethality test (BSLT), bioassay antikanker in vitro dengan sel leukemia L1210 dan isolasi serta penentuan struktur molekul senyawa kimia dari buah mahkota dewa [Phaleria macrocarpa (Schef) Boerl]. Tesis, Universitas Indonesia.

Mustafida, R. Y., A. Munawir, R. Dewi. 2014. Efek antiangiogenik ekstrak etanol buah mahkota dewa (Phaleria macrocarpa (Scheff.) Boerl) pada membran korio alantois (CAM) embrio ayam. J. Pustaka Kes. 2(1): 4-7.

Nugraha, A. S., N. S. Hadi, Rr. S. U. Siwi. 2008. Efek hepatoprotektif ekstrak buah merah (Pandanus conoideus Lam.) pada hati mencit jantan galur Swiss induksi dengan $\mathrm{CCl}_{4}$. J. Natur Indonesia 11(1): 24-30.

Poprac, P., K. Jomova, M. Simunkova, V. Kollar, C. J. Rhodes, M. Valko. 2017. Targeting free radicals in oxidative stress-related human diseases. Trends in Pharma. Sci. 38(7): 592-607.

Radji, M., H. Aldrat, Y. Harahap, C. Irawan. 2010. Uji sitotoksisitas buah merah, mahkota dewa, dan temu putih terhadap sel kanker serviks. J. Farmasi Ind. 5(1): 41-47.

Rohman, A., R. Sugeng, Y. B. Che Man. 2012. Characterization of red fruit (Pandanus conoideus Lam.) oil. Int. Food Res. J. 19(2): 563-567.

Sarunggallo, Z. L., P. Hariyadi, N. Andarwulan, E. H. Purnomo. 2015. Characterization of chemical properties, lipid profile, total phenol an tocopherol content of oil extracted from nine clones of ref fruit (Pandanus conoideus). Kasetsart J. (Nat. Sci.). 49: 237-250.

Sarunggallo, Z. L., Murtiningrum, H. T. Uhi, M. K. Roreng, A Pongsibidang. 2014. Sifat organoleptic, sifat fisik, serta kadar $\beta$-karoten dan $\alpha$ tokoferol emulsi buah merah (Pandanus conoideus). Agritech. 34(2): 177-183.

Soeksmanto, A., Y. Hapsari, P. Simanjuntak. 2007. Kandungan antioksidan pada beberapa bagian tanaman mahkota dewa, Phaleria macrocarpa (Scheff) Boerl. (Thymelaceae). Biodiversitas 8(2): 92-95.

Tjandrawinata, R. R., P. F. Arifin, O. M. Tandrasasmita, D. Rahmi, A. Aripin. 2010. DLBS1425, a Phaleria macrocarpa (Scheff.) Boerl. extract confers anti proliferative and proapoptosis effects via eicosanoid pathway. J. Exp. Ther. Oncol. 8(3): 187-201.

Tohge, T., S. Alseekh, A. R. Fernie. 2014. On the regulation and function of secondary metabolism during fruit development and ripening. J. Exp. Bot. 65(16): 4599-4611.

Treutter, D. 2001. Biosynthesis of phenolic compounds and its regulation in apple. Plant Growth Regul. 34: 7189. 